\title{
Effects of essential oils on milk production, milk composition, and rumen microbiota in Chios dairy ewes
}

\author{
I. Giannenas, ${ }^{\star 1}$ J. Skoufos,† C. Giannakopoulos,‡ M. Wiemann,§ O. Gortzi,\# S. Lalas,\# and I. Kyriazakis \\ *Laboratory of Animal Nutrition and Husbandry, Veterinary Faculty, University of Thessaly, 43100 Karditsa, Greece \\ †Department of Animal Production, TEI Epirus, 47100 Arta, Greece \\ $\ddagger$ Amnos S.A., Chios Sheep Breeding Farm, Sesklon, 37300 Volos, Greece \\ $\S D S M$ Nutritional Products Europe Ltd., CH-4002 Basel, Switzerland \\ \#Department of Food Technology, TEI Larisa, 43100 Karditsa, Greece
}

\section{ABSTRACT}

The effect of the addition of an essential oil (EO) preparation (containing a mixture of natural and nature-identical EO) on the performance of dairy ewes of the Chios breed was investigated. Eighty lactating ewes were allocated into 4 equal groups in a randomized block design, each with 4 replicates of 5 ewes housed in the same pen. The 4 groups were fed the same total mixed ration allowance, the roughage being a mixture of corn silage, lucerne hay, and wheat straw, and the concentrate based on cereals and oil cakes. Control ewes were fed their daily allowance of total mixed ration without any EO. The other 3 groups were supplemented with EO at levels of 50, 100, and $150 \mathrm{mg} / \mathrm{kg}$ of the concentrated feed, respectively. Individual milk yield was recorded daily and feed refusals were recorded on a pen basis weekly during the first 5 mo of lactation. Milk samples were analyzed for chemical composition, somatic cell count, and urea content. Rumen samples were analyzed for $\mathrm{pH}, \mathrm{NH}_{3}-\mathrm{N}$ content, and protozoa, cellulolytic, hyper-ammonia-producing, and total viable bacteria counts. Results showed that inclusion of EO increased milk production per ewe, the effect being dose dependent $[1.565,1.681,1.876$, and 2.119 $\mathrm{L} / \mathrm{d}$ (standard error of the difference \pm 0.176 ) for the control, 50, 100, and $150 \mathrm{mg}$ of $\mathrm{EO} / \mathrm{kg}$ of concentrate diets, respectively], and thus improved feed utilization. Although the inclusion of EO did not affect milk composition, it lowered urea concentration and somatic cell count in milk samples at the highest supplementation level compared with the control. Total counts of viable and cellulolytic bacteria and protozoa were not influenced by EO supplementation; however, counts of hyper-ammonia-producing bacteria were decreased at the 2 highest supplementation levels compared with

Received December 15, 2010.

Accepted July 11, 2011.

${ }^{1}$ Corresponding author: giannenas@vet.uth.gr the control group. Rumen $\mathrm{pH}$ was not affected by EO supplementation, but rumen $\mathrm{NH}_{3}-\mathrm{N}$ was reduced at the highest EO supplementation level, and acetate rumen concentrations tended to decrease and propionate to increase in a dose-dependent manner. In conclusion, EO supplementation may improve feed utilization and performance of the high-yielding dairy Chios ewes; however, the underlying mechanisms leading to this improvement merit further investigation.

Key words: Chios dairy sheep, essential oil, performance, rumen microbial populations

\section{INTRODUCTION}

The use of feed additives as a means of manipulating rumen fermentation has been investigated extensively since the 1950s (Beeson and Perry, 1952). These investigations have intensified over the last decade for two main reasons: first, to find alternative performance enhancers after the ban on the use of antibiotics as feed additives in various countries, and second, because of concerns over the environmental effects of livestock, and ruminant livestock in particular (De Gees et al., 1997). The European Union, for example, has developed directives that aim to control nutrient excretion from livestock systems by establishing limits for the annual amount of $\mathrm{N}$ released to the environment (Nitrate Directive, 91/676/EU) or gas emissions.

Plant-derived essential oils (EO) may be a useful means to improve efficiency of nutrient utilization and performance in ruminants and to reduce the effects on the environment. However, the recommended use of EO is not based on scientific evidence, but stems mainly from suggestions based on ethnoveterinary medicine (Chang, 2000; Athanasiadou and Kyriazakis, 2004). Most studies that address the efficacy of EO to date have been laboratory-based (i.e., in vitro) and short-term but indicate that EO and their active components may alter favorably ruminal fermentation patterns (Chaves et al., 2008; Khan and Chaudhry, 
2010). Several studies have shown that EO possess strong bactericidal activity against several foodborne pathogens (Ultee et al., 1999). At high doses, EO and their constituents may inhibit deamination of amino acids and decrease methane production in the rumen (Greathead, 2003). However, long-term in vitro (i.e., continuous cultures) studies suggest that the benefits associated with EO diminish over time due to shifts in microbial populations or adaptation of individual microbial species to EO (Gladine et al., 2007). The extent to which microbial pathogens exhibit a similar adaptive response to EO in vivo is presently unknown (Dorman and Deans, 2000). The range of EO and their components is complex in terms of nature and activity, and variability in their composition may make it difficult to obtain consistent responses in ruminants from these complex mixtures (Benchaar et al., 2008). Furthermore, only a small number of in vivo studies have been carried out to evaluate the effectiveness of EO.

Over the last decade, several dairy sheep farms, mainly in southern Europe, have adopted the intensive system of managing high-yielding dairy ewes. These animals are managed similarly to high-yielding dairy cows, being milked by milking machines and fed a TMR based on corn silage, lucerne hay, or grass (Broderick, 1985; Wattiaux and Karg, 2004). It is possible therefore that these animals may also benefit from the addition of EO to their diet in a manner similar to dairy cows. However, the information on the efficacy of EO fed to dairy sheep in the literature is very limited and the results are not conclusive (Chaves et al., 2008).

The objective of the present study was to investigate the effects of dietary addition of a specific mixture of EO compounds on feed utilization, milk production and composition, and rumen parameters of dairy ewes of the high-yielding Greek breed Chios fed a TMR. The hypothesis addressed in this paper was that dietary addition of a specific mixture of EO compounds would lead to improvements in feed utilization and changes in rumen microbial popultaions, which would be reflected by increases in milk production and changes in milk composition. The null hypothesis was that these effects would be dose-dependent.

\section{MATERIALS AND METHODS}

This trial was carried out according to the regulations of the Greek Public Veterinary Service and the Authorities of the Veterinary Faculty of the University of Thessaly. The health of the animals was monitored by a veterinary surgeon; animals were routinely vaccinated against enterotoxemia, contagious agalactiae, and enzootic abortion.

\section{Experimental Design and Feeding}

Eighty lactating ewes of the Chios breed were randomly selected for twin birth from a flock consisting of 630 ewes kept on the Amnos dairy breeding sheep farm located in the area of Thessaly (Sesklo, Volos, Greece). The ewes were allocated into 1 of 4 treatment groups of equal size, each comprising 4 subgroups. Each group and subgroup was balanced for BW on the date of lambing and as far as possible for parity and BCS. Each subgroup consisted of 5 ewes and was housed in a separate pen. The 4 treatment groups were fed the same ration, except for the EO supplementation. Control animals were fed the basal ration only without any EO. The diets of the other groups were supplemented with EO (Crina Ruminants, DSM Nutritional Products, Basel, Switzerland) at 50, 100, and $150 \mathrm{mg} / \mathrm{kg}$ of DM of the concentrate part of the diet, respectively. The supplement consisted of a mixture of natural and nature-identical EO compounds, including thymol, eugenol, vanillin, guaiacol, and limonene (McIntosh et al., 2003; Castillejos et al., 2005). The EO compounds of the supplement are bound to a specific organic-inorganic carrier contining benzoic acid, which ensures high stability of the effective components during storage and feed processing.

At the start of the trial, ewes were in late pregnancy (on average 1 wk before birth and lactation) and were acclimated to the experimental conditions for $1 \mathrm{wk}$ before the start of the treatments. The mean initial BW was $60.4 \pm 1.57 \mathrm{~kg}$ at parturition and the trial lasted for 5 mo (May to October 2009). The ewes were machine-milked twice daily (at 0630 and $1700 \mathrm{~h}$ ) in a double 48-stall parallel milking parlor with an identification mechanism for individual ewes.

All ewes were fed an allowance of the same TMR, which was offered twice daily. The daily forage allowance was $1.1 \mathrm{~kg}$ of lucerne hay, $0.9 \mathrm{~kg}$ of corn silage, $0.35 \mathrm{~kg}$ of wheat straw, and $0.1 \mathrm{~kg}$ of cottonseed per ewe on a fresh weight basis. The concentrate feed consisted of corn grains, barley grains, wheat bran, extracted soybean meal, sunflower cake, and mineral and vitamin premix (Table 1). The concentrate feed was fed at the level of $1.45 \mathrm{~kg} /$ ewe per day; thus, the total TMR allowance was $3.9 \mathrm{~kg}$ of fresh food/ewe per day. Feed allowance was kept constant throughout the experimental period according to commercial practice. Diet supplementation with different levels of EO was prepared daily for every group at the corresponding level by hand mixing. Table 1 shows the chemical analysis of the TMR, according to AOAC (1990). Feed (TMR) samples were collected monthly and subsequently analyzed for each group. Any orts were collected and taken 
Table 1. Daily ingredient allowance and chemical composition of the TMR offered to dairy ewes during lactation

\begin{tabular}{lc}
\hline Item & Diet \\
\hline Ingredient (fresh-weight basis, g/d per ewe) & 1,100 \\
Lucerne hay & 900 \\
Corn silage & 350 \\
Wheat straw & 640 \\
Corn & 330 \\
Barley & 150 \\
Wheat bran & 150 \\
Sunflower seed meal & 150 \\
Soybean meal & 100 \\
Cottonseed & 30 \\
Vitamin and inorganic premix ${ }^{1}$ & 3,900 \\
Total & \\
Chemical analysis (\%) & 75.3 \\
DM & 15.1 \\
CP (N $\times 6.25)$ & 2.9 \\
Ether extract & 22.5 \\
Crude fiber & 30.6 \\
NDF & 17.3 \\
ADF & 6.7 \\
Acid detergent lignin & 8.6 \\
Ash & 15.9 \\
Starch & 3.8 \\
Sugars & \\
Calculated analysis (g/kg) & 24.3 \\
P (total) & 14.5 \\
\hline Vitamin ant & \\
\hline
\end{tabular}

${ }^{1}$ Vitamin and mineral mix contained (per $\mathrm{kg}$ of DM): $7 \mathrm{mg}$ of Co, 167 $\mathrm{mg}$ of $\mathrm{Cu}, 33 \mathrm{mg}$ of I, 2,660 $\mathrm{mg}$ of $\mathrm{Mn}, 27 \mathrm{mg}$ of Se, 4,660 $\mathrm{mg}$ of $\mathrm{Zn}$, $1,000 \mathrm{kIU}$ of vitamin A, $200 \mathrm{kIU}$ of vitamin $\mathrm{D}_{3}$, and $1,330 \mathrm{mg}$ of vitamin $\mathrm{E}, 67 \mathrm{~g}$ of $\mathrm{NaCl}, 33 \mathrm{~g}$ of $\mathrm{S}, 300 \mathrm{~g}$ of $\mathrm{MgO}, 200 \mathrm{~g}$ of monocalcium phosphate, and $420 \mathrm{~g}$ of limestone.

into account in the calculations. Fresh water was available ad libitum.

\section{Milk Production and Composition}

The milk yield of each sheep was recorded daily. Individual sheep were recognized by a ruminal bolus when entering the parlor (De Laval, Hamburg, Germany). Individual milk yield was recorded automatically. Individual milk samples were analyzed for fat, protein, lactose, total solids, SNF, and urea by near-infrared spectrocopy using a MilkoScan 4000 (Foss Electric, Integrated Milk Testing, Hillerød, Denmark), and SCC were determined using a Fossomatic 5000 Basic (Foss Electric) on d 50, 100, and 150 of lactation. Milk acidity was measured by using a portable titrator (Hanna Instruments, Washington, DC).

\section{Blood Serum Parameters}

Blood samples were obtained from each ewe on $\mathrm{d}$ 150 of lactation before morning feeding by jugular venipuncture into $10-\mathrm{mL}$ vacuum tubes (Vacutainer, Becton-Dickinsin Co., Plymouth, UK). Samples were centrifuged $\left(5,000 \times g\right.$ for $20 \mathrm{~min}$ at $\left.4^{\circ} \mathrm{C}\right)$, and collected serum was frozen at $-20^{\circ} \mathrm{C}$ until analysis. Biochemical indicators were assayed by using an automated analyzer (Idexx Vet Test Chemistry Analyzer, Idexx, New York, NY).

\section{Ruminal Fermentation Characteristics and Determination of VFA}

Ruminal fluid was collected from individual ewes by puncture of the rumen wall at 0 (just before feeding), 2,4 , and $6 \mathrm{~h}$ after the $0800 \mathrm{~h}$ feeding on the last day of the trial. Samples $(25 \mathrm{~mL} /$ site $)$ were withdrawn using a metal syringe attached to a stainless-steel tube ending with a probe covered by a $50-\mu \mathrm{m}$ metal mesh (RT Rumen Fluid Collection Tube; Bar Diamond Inc., Parma, ID). To achieve a representative rumen sample, the syringe was moved at different predefined angles within the rumen. Ruminal fluid $\mathrm{pH}$ was measured immediately after sampling (Accumet $\mathrm{pH}$ meter, Mettler, Toledo, $\mathrm{OH}$ ), and then samples taken at the different time points from each animal were pooled for further analysis. Pooled samples were acidified to $\mathrm{pH}$ 2 with $50 \% \mathrm{H}_{2} \mathrm{SO}_{4}$ and frozen at $-20^{\circ} \mathrm{C}$ for subsequent determination of ammonia $\mathrm{N}\left(\mathrm{NH}_{3}-\mathrm{N}\right)$ concentrations and short-chain fatty acid analysis. On the pooled samples, VFA concentration was determined using a method adapted from Farajzadeh and Assadi (2009). The analysis was carried out on a Shimadzu CBM-20A (Shimadzu Europa GmbH, Duisburg, Germany) liquid chromatograph equipped with an auto sampler (SIL20AC) and a column oven (CTO-20AC). Detection was carried out using a Shimadzu SPD-M20A photodiode array detector.

\section{Microbial Counts}

Microbial counts were carried out on the pooled ruminal fluid samples of each animal according to Benchaar et al. (2007) on the last day of the feeding trial. Serial 10-fold dilutions of strained ruminal fluid were prepared under $95 \% \mathrm{CO}_{2}-5 \% \mathrm{H}_{2}$ in an anaerobic chamber and used as inoculum for microbial counts. Total viable counts were enumerated on triplicate layered plates, containing ruminal fluid-starch-agar medium. Cellulolytic and hyper-ammonia-producing (HAP) bacteria were counted according to Benchaar et al. (2007), and all plates were incubated at $39 \pm 1^{\circ} \mathrm{C}$. Anaerobic incubation was achieved using appropriate catalysts (Anaerocult A, Merck, Darmstadt, Germany) in sealed anaerobic jars (Oxoid, Basingstoke, UK). The confirmation of anaerobiosis was verified by Anaerotest (Merck).

A 3-mL portion of the strained ruminal fluid was preserved using $3 \mathrm{~mL}$ of methyl green formalin-saline solu- 
tion for enumeration of protozoa (Ogimoto and Imai, 1981). Protozoa samples were stored at room temperature in the dark until counting and were enumerated microscopically in a Neubauer cytometer (Hawksley, Lancing, UK). Each sample was counted twice.

\section{Statistical Analysis}

Data on total milk production and composition were analyzed as repeated measurements by ANOVA in the General Linear Model of the SPSS 17.00 statistical package (SPSS Inc., Chicago, IL). Individual ewes were considered replicates nested within pens; the pen was the statistical unit for the analysis. Data on total milk yield and composition, ruminal $\mathrm{pH}, \mathrm{NH}_{3}-\mathrm{N}$, VFA, blood parameters, and microbial populations were analyzed by one-way ANOVA; as above, pens were considered the statistical unit and ewes were replicates nested within a pen. The one-way ANOVA model was also tested for linear and quadratic responses to EO supplementation. The homogeneity of the variances was tested by Levene test. The Tukey multiple comparison test was carried out to assess any significant differences at a probability level of $P<0.05$ between the experimental treatments, when a significant effect of treatment was detected by the ANOVA.

\section{RESULTS}

One ewe from the control group developed mastitis during wk 4 of the trial and her measurements were excluded from the analysis. None of the other animals developed any health problems. Small and nonsystem- atic feed refusals were observed throughout the trial; these constituted 0.05 to $1 \%$ of the offered TMR. Ewes were thus assumed to have consumed all their offered daily TMR allowance of $3.9 \mathrm{~kg}$ of fresh feed.

\section{Milk Yield and Composition}

Milk yield followed a typical lactation curve. No interaction was found between treatment and time on daily milk yield $(P>0.05)$ over the whole lactation period, but the effect of treatment on daily milk yield was highly significant $(P<0.05$; Figure 1$)$. The inclusion of EO increased total milk yield per ewe in a dosedependent manner: average milk yield was $1.565 \mathrm{~L} / \mathrm{d}$ for control versus 1.681, 1.876, and 2.119 L/d [standard error of the difference $($ SED) $=0.176 \mathrm{~L} / \mathrm{d}]$ for the groups supplemented with 50, 100, and $150 \mathrm{mg}$ of EO/ $\mathrm{kg}$ concentrate, respectively; the trend in the increase was both linear $(P<0.05)$ and quadratic $(P<0.05)$.

The composition of the milk for the days analyzed (d 50,100 , and 150 of lactation) is shown in Table 2. No interaction was found between treatment and time for any of the parameters of milk composition analyzed. Milk fat, protein, lactose, ash, and total SNF, $\mathrm{pH}$, and acidity were not affected by dietary treatments at any of the time points $(P>0.05)$. However, an effect of $\mathrm{EO}$ supplementation was found on both milk urea content and SCC, with the highest values being observed in the control group. The effects of treatment on milk urea content were significant at all time points and were essentially linear $(P<0.05)$ for the samples taken on d 150 of lactation. Somatic cell counts were similar among the experimental groups on d 50 of the trial;

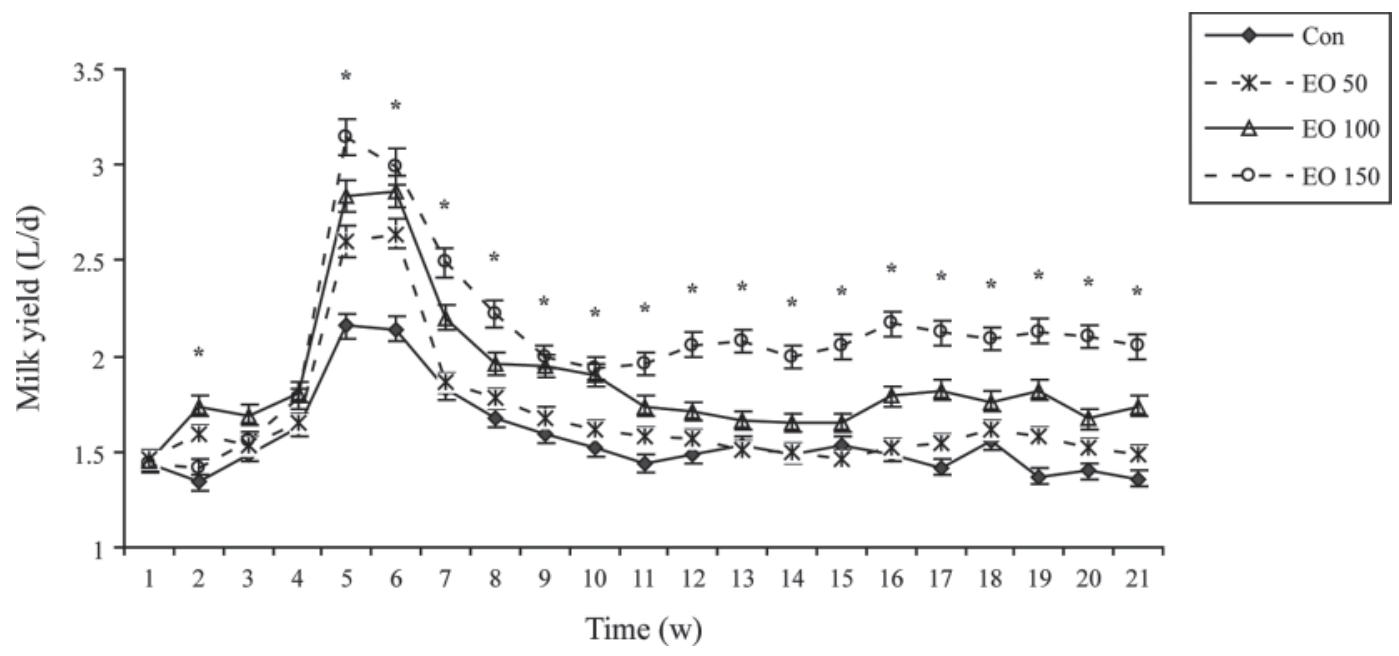

Figure 1. Effects of essential oils (Crina Ruminants, DSM Nutritional Products, Basel, Switzerland) on milk production of dairy ewes of the Chios breed. Results are given as means of groups ( $\mathrm{n}=4$ subgroups); Con, EO 50, EO 100, and EO 150 represent groups of ewes fed the basal diet supplemented with essential oils at $0,50,100$, and $150 \mathrm{mg} / \mathrm{kg}$ of concentrate. ${ }^{*} P<0.05$. 
Table 2. Effects of essential oil supplementation on milk yield, composition, and characteristics of ewes during the course of lactation ${ }^{1}$

\begin{tabular}{|c|c|c|c|c|c|c|}
\hline \multirow[b]{2}{*}{ Item } & \multicolumn{4}{|c|}{$\operatorname{Diet}^{2}$} & \multirow[b]{2}{*}{$\mathrm{SED}^{3}$} & \multirow[b]{2}{*}{$P$-value } \\
\hline & Con & EO 50 & EO 100 & EO 150 & & \\
\hline Overall milk yield (L) & $234.7^{\mathrm{b}}$ & $252.1^{\mathrm{b}}$ & $281.4^{\mathrm{a}}$ & $317.8^{\mathrm{a}}$ & 24.3 & 0.034 \\
\hline \multicolumn{7}{|l|}{ Composition } \\
\hline \multicolumn{7}{|l|}{ Day 50} \\
\hline Milk (L/d) & $1.83^{\mathrm{b}}$ & $1.86^{\mathrm{b}}$ & $2.20^{\mathrm{a}}$ & $2.49^{\mathrm{a}}$ & 0.11 & 0.031 \\
\hline Fat $(\mathrm{g} / \mathrm{d})$ & 13.1 & 13.4 & 15.9 & 17.9 & 0.89 & 0.541 \\
\hline Fat $(\%)$ & 7.15 & 7.22 & 7.25 & 7.21 & 0.35 & 0.544 \\
\hline Protein $(\mathrm{g} / \mathrm{d})$ & 10.3 & 10.6 & 12.5 & 14.3 & 0.66 & 0.542 \\
\hline Protein $(\%)$ & 5.65 & 5.72 & 5.70 & 5.75 & 0.26 & 0.638 \\
\hline Lactose $(\mathrm{g} / \mathrm{d})$ & 9.0 & 9.0 & 10.5 & 11.7 & 0.55 & 0.635 \\
\hline $\operatorname{Ash}(g / d)$ & 1.5 & 1.6 & 1.9 & 2.1 & 1.46 & 0.839 \\
\hline SNF $(\%)$ & 11.05 & 11.01 & 11.53 & 11.27 & 0.38 & 0.708 \\
\hline $\mathrm{SCC}\left(\times 10^{3} / \mathrm{mL}\right)$ & 240 & 264 & 235 & 218 & 25.6 & 0.061 \\
\hline $\mathrm{pH}$ & 6.72 & 6.71 & 6.71 & 6.72 & 0.04 & 0.812 \\
\hline Acidity (g of lactic & 22.1 & 22.2 & 22.5 & 22.2 & 0.36 & 0.802 \\
\hline \multicolumn{7}{|l|}{ acid equivalent) } \\
\hline Urea $(\mathrm{mg} / 100 \mathrm{~mL})$ & $32.97^{\mathrm{b}}$ & $40.73^{\mathrm{a}}$ & $29.97^{\mathrm{b}}$ & $21.31^{\mathrm{c}}$ & 2.95 & 0.041 \\
\hline \multicolumn{7}{|l|}{ Day 100} \\
\hline Milk (L/d) & $1.48^{\mathrm{b}}$ & $1.50^{\mathrm{b}}$ & $1.65^{\mathrm{ab}}$ & $2.00^{\mathrm{a}}$ & 0.06 & 0.046 \\
\hline Fat $(\mathrm{g} / \mathrm{d})$ & 9.8 & 10.7 & 10.2 & 14.1 & 0.57 & 0.141 \\
\hline Fat $(\%)$ & 6.67 & 7.19 & 6.19 & 7.04 & 0.34 & 0.144 \\
\hline Protein $(\mathrm{g} / \mathrm{d})$ & 8.3 & 8.1 & 8.8 & 10.8 & 0.51 & 0.511 \\
\hline Protein $(\%)$ & 5.62 & 5.40 & 5.33 & 5.41 & 0.25 & 0.515 \\
\hline Lactose $(\mathrm{g} / \mathrm{d})$ & 6.8 & 6.9 & 7.9 & 9.4 & 0.39 & 0.442 \\
\hline $\operatorname{Ash}(g / d)$ & 1.2 & 1.2 & 1.4 & 1.6 & 0.66 & 0.803 \\
\hline $\operatorname{SNF}(\%)$ & 11.05 & 11.27 & 11.01 & 10.97 & 0.66 & 0.681 \\
\hline $\mathrm{SCC}\left(\times 10^{3} / \mathrm{mL}\right)$ & $181^{\mathrm{a}}$ & $177^{\mathrm{a}}$ & $163^{\mathrm{a}}$ & $132^{\mathrm{b}}$ & 22.4 & 0.011 \\
\hline $\mathrm{pH}$ & 6.63 & 6.65 & 6.61 & 6.62 & 0.04 & 0.815 \\
\hline Acidity & 22.7 & 23.2 & 23.5 & 23.8 & 0.32 & 0.755 \\
\hline Urea $(\mathrm{mg} / 100 \mathrm{~mL})$ & $34.54^{\mathrm{a}}$ & $30.82^{\mathrm{a}}$ & $30.13^{\mathrm{a}}$ & $19.62^{\mathrm{b}}$ & 2.08 & 0.004 \\
\hline \multicolumn{7}{|l|}{ Day 150} \\
\hline Milk (L/d) & $1.36^{\mathrm{b}}$ & $1.49^{\mathrm{b}}$ & $1.74^{\mathrm{a}}$ & $2.05^{\mathrm{a}}$ & 0.05 & 0.041 \\
\hline Fat $(\mathrm{g} / \mathrm{d})$ & 9.7 & 9.6 & 10.6 & 12.6 & 0.51 & 0.064 \\
\hline Fat $(\%)$ & 7.14 & 6.43 & 6.11 & 6.18 & 0.35 & 0.064 \\
\hline Protein (g/d) & 7.2 & 8.9 & 9.8 & 11.8 & 0.46 & 0.488 \\
\hline Protein $(\%)$ & 5.31 & 5.99 & 5.63 & 5.79 & 0.26 & 0.489 \\
\hline Lactose $(\mathrm{g} / \mathrm{d})$ & 6.0 & 6.8 & 8.2 & 9.9 & 0.41 & 0.332 \\
\hline $\operatorname{Ash}(g / d)$ & 1.1 & 1.2 & 1.4 & 1.7 & 0.42 & 0.822 \\
\hline $\operatorname{SNF}(\%)$ & 11.05 & 11.01 & 11.04 & 11.06 & 0.56 & 0.698 \\
\hline $\mathrm{SCC}\left(\times 10^{3} / \mathrm{mL}\right)$ & $233^{\mathrm{a}}$ & $197^{\mathrm{b}}$ & $158^{\mathrm{b}}$ & $124^{\mathrm{c}}$ & 32.45 & 0.004 \\
\hline $\mathrm{pH}$ & 6.59 & 6.58 & 6.59 & 6.61 & 0.02 & 0.801 \\
\hline Acidity & 24.2 & 24.3 & 24.5 & 23.5 & 0.31 & 0.711 \\
\hline Urea $(\mathrm{mg} / 100 \mathrm{~mL})$ & $39.65^{\mathrm{a}}$ & $32.61^{\mathrm{b}}$ & $27.98^{\mathrm{b}}$ & $20.41^{\mathrm{c}}$ & 4.44 & 0.001 \\
\hline
\end{tabular}

${ }^{a-c}$ Values in the same row with a different superscript differ significantly at $P \leq 0.05$.

${ }^{1}$ Results are given as means of groups ( $\mathrm{n}=4$ subgroups).

${ }^{2}$ Con, EO 50, EO 100, and EO 150 represent groups of ewes fed the basal diet supplemented with essential oils at $0,50,100$, and $150 \mathrm{mg} / \mathrm{kg}$ of concentrate.

${ }^{3}$ Standard error of the difference.

${ }^{4}$ The interactions between treatment and time were not significant for any of the parameters measured.

however, on both d 100 and 150, SCC were lower for the group supplemented at $150 \mathrm{mg} / \mathrm{kg}$ of concentrate compared with the control group $(P<0.05)$.

\section{Blood Serum Parameters}

Supplementation with EO did not significantly affect total protein, albumin, or glucose in the serum $(P>$ $0.05)$ at d 150 of lactation (end of feeding trial). However, a tendency was observed for serum total protein to increase linearly $(5.52 \mathrm{~g} / \mathrm{dL}$ for control vs. $6.52,6.85$, and $7.20, \mathrm{SED}=0.64$, for the groups supplemented with 50,100 and $150 \mathrm{mg}$ of $\mathrm{EO} / \mathrm{kg}$ of concentrate, respectively; $P=0.066$ ) and for glucose serum to change quadratically $(63.1 \mathrm{~g} / \mathrm{dL}$ for control vs. $56.3,55.5$, and $63.3, \mathrm{SED}=5.58 ; P=0.089)$.

\section{Ruminal Fermentation Characteristics}

Supplementation with EO did not significantly affect either rumen $\mathrm{pH}$ values or $\mathrm{NH}_{3}-\mathrm{N}$ concentrations in the 


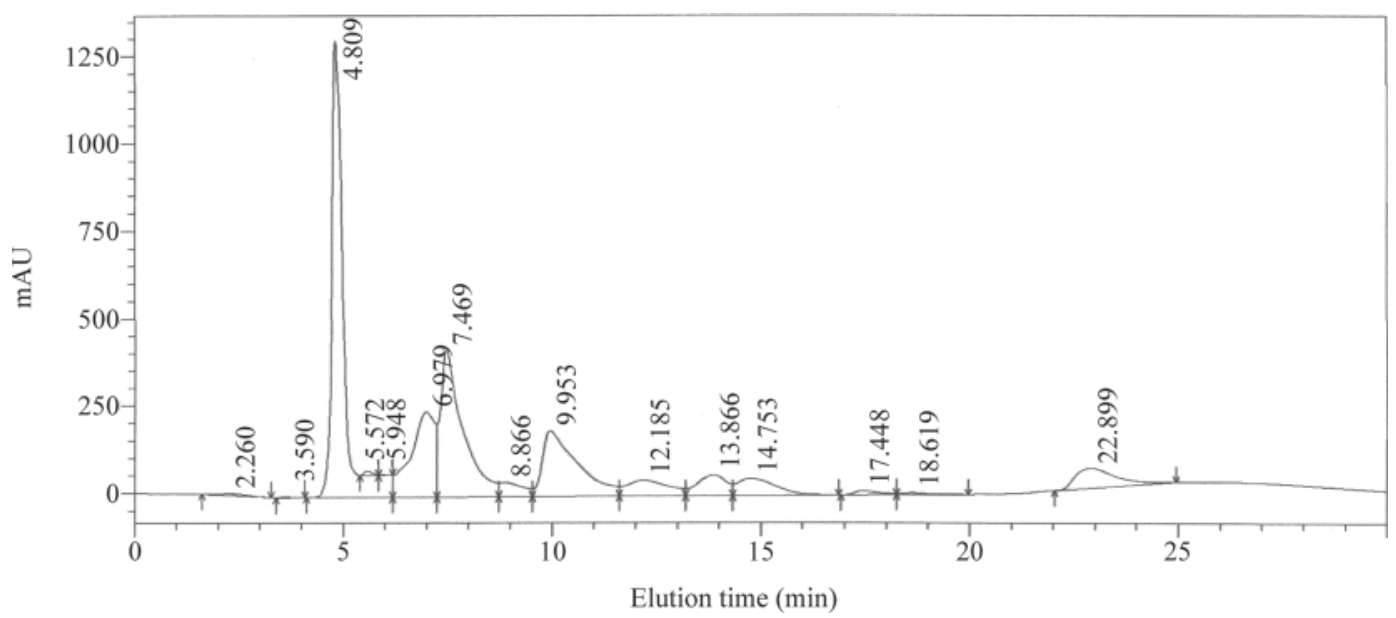

Figure 2. Chromatogram of sample 3 of the group EO 100 (animals fed the basal diet supplemented with $100 \mathrm{mg} / \mathrm{kg}$ of essential oils) for determination of VFA.

rumen samples taken at the end of the feeding trial $(\mathrm{d}$ 150; Table 3), although a tendency was observed for rumen $\mathrm{NH}_{3}-\mathrm{N}$ to decrease at the 2 highest levels of $\mathrm{EO}$ supplementation $(P=0.07)$. Volatile fatty acid values showed that acetate, butyrate, valerate, branched-chain fatty acids, and total VFA concentrations did not differ significantly between the experimental groups $(P>$ $0.05)$. However, a shift toward propionate production was observed for ewes fed 100 and $150 \mathrm{mg}$ of $\mathrm{EO} / \mathrm{kg}$; this increase was essentially linear $(P<0.05)$. Con- sequently, the acetate to propionate ratio was highest in the control group and lowest in the ewes fed 150 $\mathrm{mg}$ of $\mathrm{EO} / \mathrm{kg}(P<0.05)$. Figure 2 shows the different chromatographic peaks of VFA.

\section{Ruminal Microbiota}

Total viable bacteria and protozoa counts were not influenced by EO supplementation $(P>0.05)$. However, cellulolytic bacteria numbers were increased $(P$

Table 3. Effects of essential oil supplementation on rumen microbial population and fermentation parameters in samples taken from dairy ewes on d 150 of lactation $^{1}$

\begin{tabular}{|c|c|c|c|c|c|c|}
\hline \multirow[b]{2}{*}{ Parameter } & \multicolumn{4}{|c|}{ Diet $^{2}$} & \multirow[b]{2}{*}{$\mathrm{SED}^{3}$} & \multirow[b]{2}{*}{$P$-value } \\
\hline & Con & EO 50 & EO 100 & EO 150 & & \\
\hline \multicolumn{7}{|l|}{ Microbial counts } \\
\hline Total viable bacteria $\left(\times 10^{9} / \mathrm{mL}\right)$ & 2.42 & 3.41 & 3.32 & 2.28 & 0.48 & 0.124 \\
\hline Cellulolytic bacteria $\left(\times 10^{7} / \mathrm{mL}\right)$ & $3.82^{\mathrm{b}}$ & $5.31^{\mathrm{a}}$ & $5.61^{\mathrm{a}}$ & $5.74^{\mathrm{a}}$ & 0.68 & 0.044 \\
\hline $\operatorname{HAP}^{4}$ bacteria $\left(\times 10^{7} / \mathrm{mL}\right)$ & $5.32^{\mathrm{a}}$ & $4.71^{\mathrm{b}}$ & $4.61^{\mathrm{b}}$ & $4.22^{\mathrm{c}}$ & 0.48 & 0.031 \\
\hline Protozoa $\left(\times 10^{5} / \mathrm{mL}\right)$ & 4.02 & 5.22 & 4.78 & 5.37 & 1.06 & 0.125 \\
\hline $\mathrm{pH}$ & 6.52 & 6.59 & 6.71 & 6.74 & 0.04 & 0.718 \\
\hline $\mathrm{NH}_{3}-\mathrm{N}(\mathrm{mg} / 100 \mathrm{~mL})$ & 7.79 & 8.22 & 7.45 & 7.57 & 0.65 & 0.066 \\
\hline Total VFA $(\mathrm{m} M)$ & 115.2 & 108.3 & 119.6 & 126.2 & 16.28 & 0.078 \\
\hline \multicolumn{7}{|l|}{ VFA (mol/100 mol) } \\
\hline Acetate (A) & 67.4 & 64.8 & 63.7 & 62.7 & 4.04 & 0.061 \\
\hline Propionate $(\mathrm{P})$ & $19.6^{\mathrm{b}}$ & $21.2^{\mathrm{b}}$ & $23.2^{\mathrm{ab}}$ & $24.9^{\mathrm{a}}$ & 1.14 & 0.041 \\
\hline Butyrate & 9.95 & 10.72 & 9.48 & 8.93 & 0.12 & 0.155 \\
\hline Isobutyrate & 0.79 & 0.98 & 0.99 & 0.95 & 0.11 & 0.081 \\
\hline Valerate & 1.22 & 1.24 & 1.34 & 1.27 & 0.18 & 0.144 \\
\hline Isovalerate & 1.03 & 1.01 & 1.28 & 1.24 & 0.14 & 0.211 \\
\hline $\mathrm{A}: \mathrm{P}$ & $3.44^{\mathrm{a}}$ & $3.06^{\mathrm{b}}$ & $2.75^{\mathrm{b}}$ & $2.51^{\mathrm{c}}$ & 0.28 & 0.033 \\
\hline
\end{tabular}

${ }^{a-c}$ Values in the same row with a different superscript differ significantly at $P \leq 0.05$.

${ }^{1}$ Results are given as means of groups ( $\mathrm{n}=4$ subgroups).

${ }^{2}$ Con, EO 50, EO 100, and EO 150 represent groups of ewes fed the basal diet supplemented with essential oils at $0,50,100$, and $150 \mathrm{mg} / \mathrm{kg}$ of concentrate.

${ }^{3}$ Standard error of the difference.

${ }^{4}$ Hyper-ammonia-producing bacteria. 
$<0.05)$ and HAP bacteria were decreased $(P<0.05)$ by EO supplementation. In both cases, the effects were essentially linear $(P<0.05)$

\section{DISCUSSION}

The objective of this study was to investigate whether dietary addition of a specific mixture of EO compounds could improve milk production and composition and affect rumen parameters in dairy ewes of the Chios breed fed the same allowance of a TMR based on corn silage and lucerne hay as the main forage sources. The Chios breed is a relatively high-yielding one (Basdagianni et al., 2005) and is increasingly maintained in the Mediterrenean basin under intensive indoor conditions that resemble those used for high-yielding dairy cows.

The prohibited use of ionophores such as monensin as additives in the European Union and the increased interest in naturally occurring additives that can also be used in organic production of ruminant milk and meat have resulted in a great deal of interest in identifying naturally occurring compounds that positively affect ruminal fermentation and performance (Santos et al., 2010). However, the published research base in relation to such EO effects is limited, and any such research has focused mainly on dairy cows (Santos et al., 2010).

In our trial, feeding dairy ewes with an EO mixture increased milk production compared with the unsupplemented control group (Table 2). Because intake was the same between the different treatment groups and throughout the trial period, feed efficiency must also have considerably improved for the EO-supplemented groups. Although we did not measure any changes in body composition, casual observations did not suggest that the effects of EO supplementation were achieved through changes in body mobilization between the treatments. The increase in milk yield was essentially linear. However, the response apparently reached a plateau at the highest level of EO inclusion, because the quadratic effect of the dose reponse was also highly significant. No interaction was observed between EO addition and milk composition, except for urea and SCC, which were found to be significantly lower in the higher EO-supplemented groups (Table 3). The effects on urea and SCC could be partly a dilution effect. Our findings on milk composition agree in part with those of Benchaar et al. (2006), who found no change in milk concentrations of fat, protein, urea $\mathrm{N}$, and milk yields of fat, protein, and lactose contents of cows fed up to $2 \mathrm{~g} / \mathrm{d}$ of the same supplement daily. Below we attempt to account for these effects of EO supplementation.
Supplementation with EO did not affect ruminal pH values. Similarly, Newbold et al. (2004), Castillejos et al. (2007), and Meyer et al. (2009) did not detect any differences in rumen $\mathrm{pH}$ when $\mathrm{EO}$ mixtures were administered in the diets of dairy cows. On the other hand, Benchaar et al. (2006, 2007) reported a slight increase in rumen $\mathrm{pH}$ values in dairy cows when supplementing with $750 \mathrm{mg} / \mathrm{d}$ of the same EO mixture. The difference in these results may be explained in part by the type of diets and animals used, with slightly greater $\mathrm{pH}$ values being reported when the EO mixture was supplemented to animals consuming diets with a higher content of roughage compared with concentrates. Conversely, ruminal $\mathrm{NH}_{3}-\mathrm{N}$ values were affected by addition of EO in our trial. This is in agreement with the in vitro results of Newbold et al. (2004), who observed a decrease in the rate of $\mathrm{NH}_{3}-\mathrm{N}$ production when rumen contents of cows or sheep supplemented with EO and acid-hydrolyzed protein were incubated for 24 to $48 \mathrm{~h}$ in strained ruminal fluid (1 or $110 \mathrm{mg} / \mathrm{d}$, respectively; Crina Ruminants). In our trial, total VFA concentrations were also affected by dietary treatment. A shift toward propionate production and a tendency to decrease acetate concentrations was seen in the ewes fed 100 and $150 \mathrm{mg}$ of $\mathrm{EO} / \mathrm{kg}$. It has been reported that total VFA concentrations could decrease (Varga et al., 2004), increase (Castillejos et al., 2005), or be unaffected (Newbold et al., 2004; Benchaar et al., 2007; Castillejos et al., 2007) when different EO compounds are supplemented to ruminant diets. Because many studies evaluating EO mixtures have been conducted using both in vitro and in vivo systems with diets containing similar or greater dietary proportions of forage than used in our study, comparisons between studies should be made with caution. Many of the effects of EO on ruminal fermentation may interact with rumen $\mathrm{pH}$ (Cardozo et al., 2004). In our trial, diet composition, $\mathrm{DM}$ intake, and rumen $\mathrm{pH}$ values were similar between the experimental groups and thus, these factors could not have influenced VFA concentrations.

The observed changes in feed utilization and VFA concentrations could be accounted for in part by changes in the rumen microbial populations. A causal explanation of how EO mixtures affect ruminal fermentation patterns through microorganism modification has not been clearly established. Evans and Martin (2000) examined the effects of thymol on ruminal microorganisms. Thymol, which is a constituent of the EO mixture tested here, inhibited gram-positive bacteria (Streptococcus bovis JB1) at $180 \mu \mathrm{g}$ of thymol/mL and gram-negative bacteria (Selenomonas ruminantium HD4) at $90 \mu \mathrm{g}$ of thymol $/ \mathrm{mL}$. Although these in vitro 
concentrations are much greater than the theoretical expected concentration of the mixtures tested in our experiment, bacterial inhibition could be a potential cause of the altered fermentation patterns observed.

Total viable bacteria and protozoa counts were not changed by the addition of EO in the diet. However, cellulolytic bacteria were increased in the EO-supplemented groups compared with the control group, but did not differ between the EO-supplemented groups; that is, the effect was not dose-dependent. Hyperammonia-producing bacteria were also decreased in the groups supplemented with EO at 100 and 150 $\mathrm{mg} / \mathrm{kg}$ of concentrate in a dose-dependent manner. Several authors have suggested certain effects of EO compounds on specific bacterial populations. However, such effects of EO on ruminal microbial populations are inconclusive (Wallace et al., 2008). Duval et al. (2007) suggested that EO compounds had an effect on specific bacterial colonization of starch-rich substrates in the rumen, and McIntosh et al. (2003) determined that activity of ruminal protozoa was affected by EO treatment at $100 \mathrm{mg} / \mathrm{kg}$. On the other hand, Newbold et al. (2004) reported an absence of an effect with the same mixture of EO supplemented at $110 \mathrm{mg} / \mathrm{d}$ on the total number of protozoa in the ruminal fluid of meattype sheep, and Benchaar et al. (2007) observed no response in protozoal populations when EO compounds were administered at $750 \mathrm{mg} / \mathrm{d}$ in dairy cows. We suggest that the inconsistencies between studies could also be due to different doses of EO used or the different prevailing feeding conditions. For instance, Castillejos et al. (2006) observed that eugenol decreased the $\mathrm{NH}_{3}$ $\mathrm{N}$ concentration when added at a dose of $5,000 \mathrm{mg} / \mathrm{L}$ in 24-h in vitro batch-culture fermentations, but no effects were reported at doses of 5,50 , and $500 \mathrm{mg} / \mathrm{L}$. Wallace et al. (2002) observed no change in total viable bacteria counts in sheep fed high- or low-protein diets supplemented with $100 \mathrm{mg} / \mathrm{d}$ of Crina Ruminants. The results suggest that the effects of EO on ruminal microbial fermentation may be dose-dependent and that these compounds are more effective when administered at high doses than at low doses. Currently, several commercially available EO products are fed to ruminants, including dairy animals, in many parts of the world (for reviews, see Wallace, 2004; Wallace et al., 2008). These products appear to lead to different consequences, some of which have been referred to above. The EO complex used in our study included eugenol (found in clove oil, nutmeg, and cinnamon), geranyl acetate (found in numerous naturally occurring EO), and coriander oil (found in coriander seeds; Benchaar et al., 2008). The composition of the EO mixture and the conditions under which it is supplemented could greatly influence the observed outcomes. If we are to exploit the properties of EO effectively, future research efforts should focus on defining the specific types and doses of EO that result in favorable but also consistent responses.

\section{CONCLUSIONS}

Addition of a specific mixture of EO compounds, especially at doses of 100 and $150 \mathrm{mg}$ /ewe per day, had significant effects on milk production, urea concentration, and SCC in milk samples. Rumen urea, priopionate and acetate concentrations, and microbial popultaions were affected by dietary addition of EO during the early lactation of dairy ewes of Chios breed. Long-term in vivo research trials are required to validate these results on dairy sheep under various management conditions and to elucidate the mechansisms of the action.

\section{REFERENCES}

AOAC. 1990. Official Methods of Analysis. 15th ed. AOAC, Arlington, VA.

Athanasiadou, S., and I. Kyriazakis. 2004. Plant secondary metabolites: Antiparasitc effects and their role in ruminant production systems. Proc. Nutr. Soc. 63:631-639.

Basdagianni, Z., G. Banos, Z. Abas, G. Arsenos, G. E. Valergakis, and D. Zygoyiannis. 2005. Estimation of daily and total lactation milk yield of Chios ewes from single morning or evening records. Livest. Prod. Sci. 92:59-68.

Beeson, W. M., and T. W. Perry. 1952. Balancing the nutritional deficiencies of roughages for beef steers. J. Anim. Sci. 11:501-515.

Benchaar, C., S. Calsamiglia, A. V. Chaves, G. R. Fraser, D. Colombatto, T. A. McAllister, and K. A. Beauchemin. 2008. A review of plant-derived essential oils in ruminant nutrition and production. Anim. Feed Sci. Technol. 145:209-228.

Benchaar, C., H. V. Petit, R. Berthiaume, D. R. J. Ouellet, R. Chiquette, and P. Y. Chouinard. 2007. Effects of essential oils on digestion, ruminal fermentation, rumen microbial populations, milk production, and milk composition in dairy cows fed alfalfa silage or corn silage. J. Dairy Sci. 90:886-897.

Benchaar, C., H. V. Petit, R. Berthiaume, T. D. Whyte, and P. Y. Chouinard. 2006. Effects of dietary addition of essential oils and monensin premix on digestion, ruminal fermentation characteristics, milk production, and milk composition in dairy cows. J. Dairy Sci. 89:4352-4364.

Broderick, G. A. 1985. Alfalfa silage or hay versus corn silage as the sole forage source for lactating dairy cows. J. Dairy Sci. 68:32623271.

Cardozo, P. W., S. Calsamiglia, A. Ferret, and C. Kamel. 2004. Effects of plant extracts on ruminal protein degradation and fermentation profiles in continuous culture. J. Anim. Sci. 82:3230-3236.

Castillejos, L., S. Calsamiglia, and A. Ferret. 2006. Effect of essential oil active compounds on rumen microbial fermentation and nutrient flow in in vitro systems. J. Dairy Sci. 89:2649-2658.

Castillejos, L., S. Calsamiglia, A. Ferret, and R. Losa. 2005. Effects of a specific blend of essential oil compounds and the type of diet on rumen microbial fermentation and nutrient flow from a continuous culture system. Anim. Feed Sci. Technol. 119:29-41.

Castillejos, L., S. Calsamiglia, A. Ferret, and R. Losa. 2007. Effects of dose and adaptation time of a specific blend of essential oil compounds on rumen fermentation. Anim. Feed Sci. Technol. 132:186-201.

Chang, J. 2000. Medicinal herbs: Drugs or dietary supplements? Biochem. Pharmacol. 59:211-219.

Chaves, A. V., K. Stanford, M. E. R. Dugan, L. L. Gibson, T. A. McAllister, F. Van Herk, and C. Benchaar. 2008. Effects of cin- 
namaldeheyde, garlic and juniper berry essential oils on rumen fermentation, blood metabolites, growth performance, and caracass characteristics of growing lambs. Livest. Sci. 117:215-224.

De Gees, H., H. Steinfeld, and H. D. Blackburn. 1997. Livestock and the Environment: Finding a Balance. European Commission Directorate-General for Development, Development Policy Sustainable Development and Natural Resources, Brussels, Belgium.

Dorman, H. J. D., and S. G. Deans. 2000. Antimicrobial agents from plants: Antibacterial activity of plant volatile oils. J. Appl. Microbiol. 88:308-316.

Duval, S. M., N. R. McEwan, R. C. Graham, R. J. Wallace, and C. J. Newbold. 2007. Effect of a blend of essential oil compounds on the colonization of starch-rich substrates by bacteria in the rumen. J. Appl. Microbiol. 103:2132-2141.

Evans, J. D., and S. A. Martin. 2000. Effects of thymol on ruminal microorganisms. Curr. Microbiol. 41:336-340.

Farajzadeh, M. A., and A. Assadi. 2009. Liquid-gas-liquid technique for microextraction and preconcentration of short-chain fatty acids from aqueous samples. J. Sep. Sci. 32:1027-1035.

Gladine, C., E. Rock, C. Morand, D. Bauchart, and D. Durand. 2007. Bioavailability and antioxidant capacity of plant extracts rich in polyphenols, given as a single acute dose, in sheep made highly susceptible to lipoperoxidation. Br. J. Nutr. 98:691-701.

Greathead, H. 2003. Plants and plant extracts for improving animal productivity. Proc. Nutr. Soc. 62:279-290.

Khan, M. M. H., and A. S. Chaudhry. 2010. Chemical composition of selected forages and spices and the effect of these spices on in vitro rumen degradability of some forages. Asian-australas. J. Anim. Sci. 23:889-895.

McIntosh, F. M., P. Williams, R. Losa, R. J. Wallace, D. A. Beever, and C. J. Newbold. 2003. Effects of essential oils on ruminal microorganisms and their protein metabolism. Appl. Environ. Microbiol. 69:5011-5014.
Meyer, N. F., G. E. Erickson, T. J. Klopfenstein, M. A. Greenquist, M. K. Luebbe, P. Williams, and M. A. Engstrom. 2009. Effect of essential oils, tylosin, and monensin on finishing steer performance, carcass characteristics, liver abscesses, ruminal fermentation, and digestibility. J. Anim. Sci. 87:2346-2354.

Newbold, C. J., F. M. McIntosh, P. Williams, R. Losa, and R. J. Wallace. 2004. Effects of a specific blend of essential oil compounds on rumen fermentation. Anim. Feed Sci. Technol. 114:105-112.

Ogimoto, K., and S. Imai. 1981. Techniques of rumen microbiology. Page 185 in Atlas of Rumen Microbiology. Japan Scientific Societies Press, Tokyo, Japan.

Santos, M. B., P. H. Robinson, P. Williams, and R. Losa. 2010. Effects of addition of an essential oil complex to the diet of lactating dairy cows on whole tract digestion of nutrients and productive performance. Anim. Feed Sci. Technol. 157:64-71.

Ultee, A., E. P. W. Kets, and E. J. Smid. 1999. Mechanisms of action of carvacrol on the food borne pathogen Bacillus cereus. Appl. Environ. Microbiol. 65:4606-4610.

Varga, G., E. Block, P. Williams, T. W. Cassidy, and R. Losa. 2004. Effect of Crina Ruminants, a mixture of essential oil components, on continuous culture fermentation and milk production of lactating cows. J. Anim. Sci. 82(Suppl. 1):334.

Wallace, R. J. 2004. Antimicrobial properties of plant secondary metabolites. Proc. Nutr. Soc. 63:621-629.

Wallace, R. J., D. Colombatto, and P. H. Robinson. 2008. Enzymes, direct-fed microbials and plant extracts in ruminant nutrition. Anim. Feed Sci. Technol. 145:1-4.

Wallace, R. J., N. R. McEwan, F. M. McIntosh, B. Teferedegne, and C. J. Newbold. 2002. Natural products as manipulators of rumen fermentation. Asian-australas. J. Anim. Sci. 10:1458-1468.

Wattiaux, M. A., and K. L. Karg. 2004. Protein level for alfalfa and corn silage-based diets: I. Lactational response and milk urea nitrogen. J. Dairy Sci. 87:3492-3502. 